Bull. Mater. Sci., Vol. 23, No. 4, August 2000, pp. 305-307. (C) Indian Academy of Sciences.

\title{
Calcium ferrite formation from the thermolysis of calcium tris (maleato) ferrate(III) ${ }^{\dagger}$
}

\author{
B S RANDHAWA* and KAMALJEET SWEETY \\ Department of Chemistry, Guru Nanak Dev University, Amritsar 143 005, India
}

\begin{abstract}
For preparing calcium ferrite, calcium tris (maleato) ferrate(III) precursor was prepared by mixing aqueous solutions of iron(III) maleate, calcium maleate and maleic acid. Various physico-chemical techniques i.e. TG, DTG, DTA, Mössbauer, XRD, IR etc have been used to study the decomposition behaviour from ambient to $900^{\circ} \mathrm{C}$ and ferrite formation. Three consecutive decomposition steps leading to the formation of $\alpha-\mathrm{Fe}_{2} \mathrm{O}_{3}$ and calcium carbonate have been observed at various stages of thermolysis. In the final stage the ferrite, $\mathrm{Ca}_{2} \mathrm{Fe}_{2} \mathrm{O}_{5}$, is obtained as a result of solid state reaction between $\alpha-\mathrm{Fe}_{2} \mathrm{O}_{3}$ and calcium carbonate at $\mathbf{7 8 8}^{\circ} \mathrm{C}$, a temperature much lower than for ceramic method. The results have been compared with those of the oxalate precursor.
\end{abstract}

Keywords. Ferrites; thermal decomposition; precursor technique; calcium ferrimaleate.

\section{Introduction}

Because of their extensive application in radio, television, microwave and satellite communication, bubble devices, audio-video, digital recording and as permanent magnets (Viswanathan and Murthy 1990), ferrites have opened a new vista in the field of chemical physics of materials. Keeping in view these technological applications, ferrites have been regarded as an important class of magnetic materials. The excellent combination of electrical and magnetic characteristics apart from the appreciable temperature performance have made the ferrite materials highly suitable for microwave application. Since the formation of ferrites by the conventional ceramic method has several disadvantages viz. nonhomogeneity, large particle size, low surface area and poor sinterability, the precursor technique has been successfully applied for the preparation of ferrites (Bassi et al 1989; Randhawa et al 1996; Randhawa and Sweety 1998). This method involves the preparation of precursor (metal ferricarboxylate) by chemical means and its decomposition into ferrites.

\section{Experimental}

Calcium tris (maleato) ferrate(III) was prepared by mixing stoichiometric quantities of aqueous solutions of calcium maleate, iron(III) maleate and maleic acid. The reaction mixture was concentrated on a water bath until a brown coloured product formed after the addition of excess of acetone. The complex was vacuum dried and its identity

*Author for correspondence

†Paper presented at the 5th IUMRS ICA98, October 1998, Bangalore. was established by chemical analysis. The infrared (IR) spectra of the complex and products were recorded on Pye-Unicam SP3-300 IR spectrophotometer in the range 4000-200 $\mathrm{cm}^{-1}$ using $\mathrm{KBr}$ pellet technique. Simultaneous TG, DTG and DTA curves were recorded on Stanton Redcroft STA-780 at a heating rate of $10^{\circ} \mathrm{mm}^{-1}$. XRD powder pattern was recorded at USIC, University of Roorkee, Roorkee. Mössbauer measurements were made at laboratoire de physique de l'etat condense, CNRS, France. All the spectra were fitted to the Lorentzian shape. The isomer shift values are reported with respect to pure iron absorber.

\section{Results and discussion}

The IR spectrum of calcium tris (maleato) ferrate(III) shows a small but distinct band at about $2850 \mathrm{~cm}^{-1}$ due to $v(\mathrm{C}-\mathrm{H})$ of the maleate group. A broad band centred at about $1620 \mathrm{~cm}^{-1}$ due to overlapping of $v(\mathrm{C}=\mathrm{C})$ and $v_{\text {asy }}(\mathrm{C}=\mathrm{O})$ has been observed. Bands in the range 1435$1315 \mathrm{~cm}^{-1}$ indicate $v_{\text {sym }}(\mathrm{C}=\mathrm{O})$ of the coordinated carboxylate group (Nakamoto 1970). A sharp band at $860 \mathrm{~cm}^{-1}$ is assigned to cis $(\mathrm{C}-\mathrm{H})$ wagging while another distinct band at $560 \mathrm{~cm}^{-1}$ reveals the presence of $\mathrm{Fe}-\mathrm{O}$ (carboxylate) bonding (Ferraro et al 1967), Mössbauer spectrum of the precursor at $300 \mathrm{~K}$ displays a doublet with isomer shift and quadrupole splitting values of 0.41 and $0.68 \mathrm{~mm} \mathrm{~s}^{-1}$ respectively. These parameters agree with those reported for high spin Fe(III) complexes with octahedral geometry (Vertes et al 1979). The six-coordination number of iron is satisfied by three maleate ligands which are bound through oxygen atoms of the carboxyl group.

Figure 1 shows the simultaneous thermograms (TG, DTG, DTA) of calcium tris (maleato) ferrate(III) at a 
heating rate of $10^{\circ} \mathrm{min}^{-1}$. The complex is anhydrous and starts decomposing at $170^{\circ} \mathrm{C}$ until a mass loss of $18 \%$ is reached at $310^{\circ} \mathrm{C}$ indicating the formation of iron(II) maleate and calcium maleate (calc. loss $18.1 \%$ ). DTG shows a respective peak at $237^{\circ} \mathrm{C}$. The iron(II) species could not be detected due to its instability. It was formed in an endostep which subsequently becomes exo in a continuously heated system and hence undergoes oxidative decomposition to yield $\mathrm{Fe}_{2} \mathrm{O}_{3}$ at a mass loss of $34 \%$ at $360^{\circ} \mathrm{C}$ (calc. loss $32.09 \%$ ). The respective DTG peak exists at $330^{\circ} \mathrm{C}$.

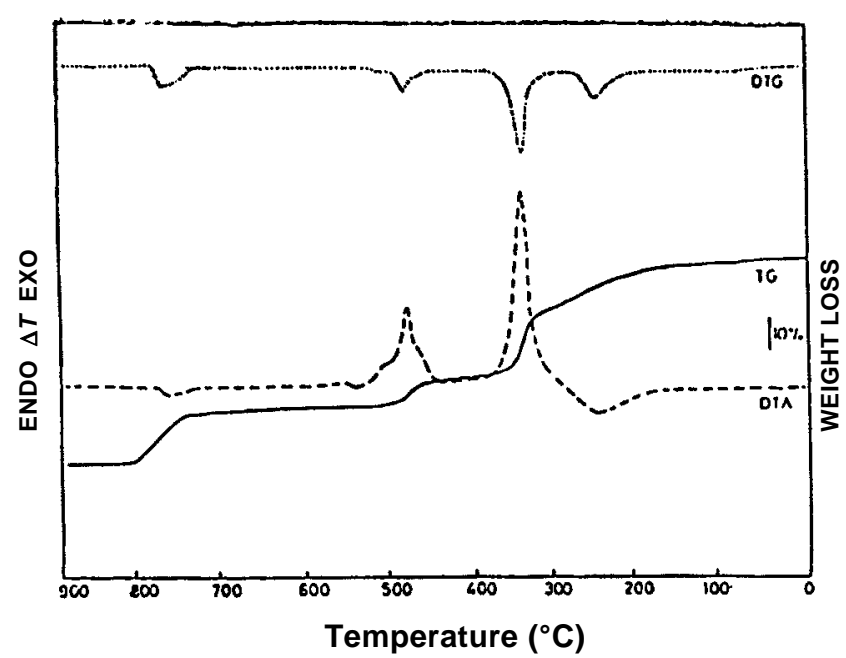

Figure 1. STA curves of the maleato complex at a heating rate of $10^{\circ} \mathrm{min}^{-1}$.

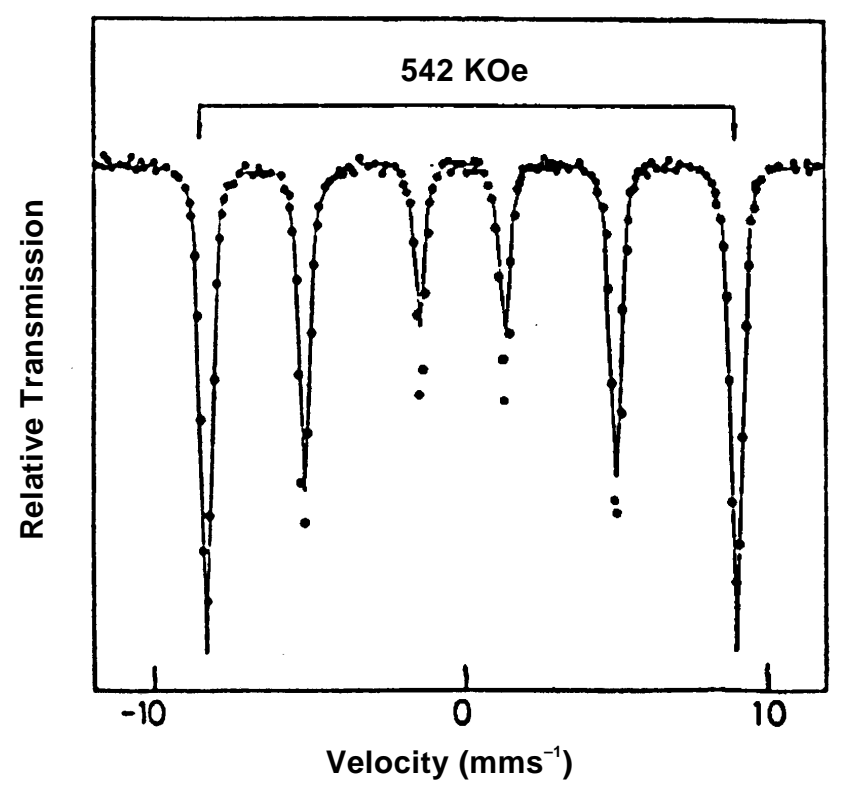

Figure 2. Mössbauer spectrum of the residue obtained at $360^{\circ} \mathrm{C}$.
The existence of $\mathrm{Fe}_{2} \mathrm{O}_{3}$ has been confirmed by the Mössbauer spectrum of the residue obtained by calcining the parent complex isothermally at $360^{\circ} \mathrm{C}$ for $1 \mathrm{~h}$. The sextet obtained at $77 \mathrm{~K}$ (figure 2) in the spectrum with isomer shift and internal magnetic field values of $0.46 \mathrm{~mm} \mathrm{sec}^{-1}$ and $542 \mathrm{KOe}$, respectively agree with those reported for $\alpha-\mathrm{Fe}_{2} \mathrm{O}_{3}$ (Cox et al 1962). An arrest in TG curve at a mass loss of $48 \%$ suggests the formation of calcium carbonate (calc. loss $49.7 \%$ ) through an intermediate step in which calcium oxalate is formed. These thermal changes are accompanied by the overlapping peaks in DTA (exo) and DTG thermograms. Calcium carbonate thus formed remains stable up to $720^{\circ} \mathrm{C}$, and then undergoes a solid-solid reaction with $\alpha-\mathrm{Fe}_{2} \mathrm{O}_{3}$ to form calcium ferrite i.e. $\mathrm{Ca}_{2} \mathrm{Fe}_{2} \mathrm{O}_{5}$, with the evolution of $\mathrm{CO}_{2}$ as revealed by a characteristic endotherm at $745^{\circ} \mathrm{C}$. The identity of the final thermolysis product as $\mathrm{Ca}_{2} \mathrm{Fe}_{2} \mathrm{O}_{5}$ has been confirmed by its Mössbauer spectra recorded both at $77 \mathrm{~K}$ (figure 3 ) and $300 \mathrm{~K}$ each exhibiting two overlapping sextets due to the distribution of $\mathrm{Fe}^{3+}$ in octahedral and tetrahedral sites. The parameters of the sextets, listed in table 1, resemble to those reported for $\mathrm{Ca}_{2} \mathrm{Fe}_{2} \mathrm{O}_{5}$ (Greenwood and Gibb 1971; Grenier et al 1997). The higher internal magnetic field values at $77 \mathrm{~K}$ as compared to $300 \mathrm{~K}$ are expected as the magnitude of this parameter is temperature dependent (Bhide 1973; Kulkarni et al 1994).

The ferrite has been obtained at a much lower temperature $\left(788^{\circ} \mathrm{C}\right)$ and also in a shorter time interval as compared to that of the ceramic method. This temperature of ferrite formation is even lower than that of the one obtained from the thermolysis of oxalate/malonate precursors $\left(>800^{\circ} \mathrm{C}\right)$. Another attractive feature of the method

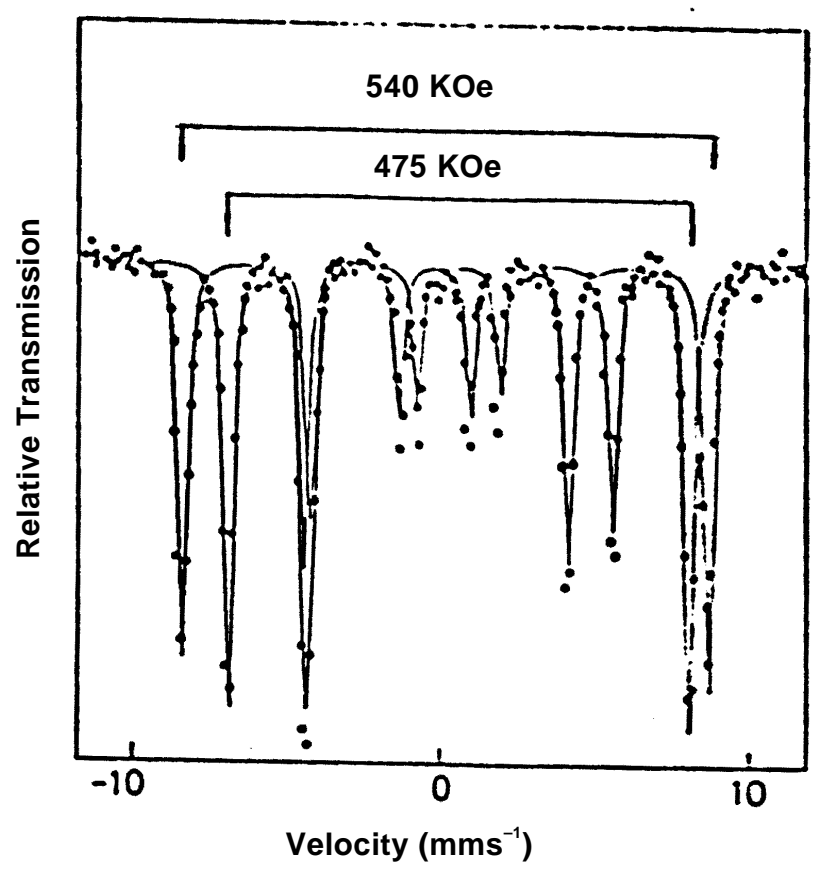

Figure 3. Mössbauer spectrum of the final thermolysis product. 
Table 1. Mössbauer parameters for thermolysis products of $\mathrm{Ca}_{3}\left[\mathrm{Fe}(\mathrm{OX})_{3}\right]_{2}$ at $77 \mathrm{~K}$.

\begin{tabular}{lccccc}
\hline $\begin{array}{l}\text { Heating temp. } \\
\left({ }^{\circ} \mathrm{C}\right)\end{array}$ & $\begin{array}{c}\delta \\
\left(\mathrm{mms}^{-1}\right)\end{array}$ & $\begin{array}{c}\Delta \mathrm{EQ} \\
\left(\mathrm{mms}^{-1}\right)\end{array}$ & $\begin{array}{c}\mathrm{HI} \\
(\mathrm{KOe})\end{array}$ & $\begin{array}{c}\mathrm{Fe}^{3} \\
(\text { Distr. \%) }\end{array}$ & Assignment \\
\hline 360 & 0.46 & - & 542 & - & $\alpha-\mathrm{Fe}_{2} \mathrm{O}_{3}$ \\
800 & 0.46 & -0.52 & 540 & 47.4 (oct) & $\mathrm{Ca}_{2} \mathrm{Fe}_{2} \mathrm{O}_{5}$ \\
& 0.27 & 0.71 & 475 & 52.6 (tet) & \\
& 0.37 & -0.52 & 504 & 45 (oct) & $\mathrm{Ca}_{2} \mathrm{Fe}_{2} \mathrm{O}_{5}^{*}$ \\
& 0.18 & 0.72 & 429 & 55 (tet) & \\
\hline
\end{tabular}

*Recorded at $300 \mathrm{~K}$.

Table 2. XRD data for the final thermolysis product.

\begin{tabular}{lrl}
\hline$d(\AA)$ & $I / I_{0}$ & Assignment \\
\hline 3.478 & 34 & $\mathrm{Ca}_{2} \mathrm{Fe}_{2} \mathrm{O}_{5}^{\mathrm{a}}$ \\
2.693 & 10 & $\mathrm{Ca}_{2} \mathrm{Fe}_{2} \mathrm{O}_{5}$ \\
2.666 & 20 & $\mathrm{Ca}_{2} \mathrm{Fe}_{2} \mathrm{O}_{5}$ \\
2.391 & 10 & $\mathrm{Ca}_{2} \mathrm{Fe}_{2} \mathrm{O}_{5}$ \\
$2 \cdot 192$ & 22 & $\mathrm{Ca}_{2} \mathrm{Fe}_{2} \mathrm{O}_{5}$ \\
2.075 & 5 & $\mathrm{Ca}_{2} \mathrm{Fe}_{2} \mathrm{O}_{5}$ \\
2.070 & 100 & $\mathrm{Ca}_{2} \mathrm{Fe}_{2} \mathrm{O}_{5}, \mathrm{CaO}^{\mathrm{b}}$ \\
1.928 & 10 & $\mathrm{Ca}_{2} \mathrm{Fe}_{2} \mathrm{O}_{5}$ \\
1.876 & 8 & $\mathrm{Ca}_{2} \mathrm{Fe}_{2} \mathrm{O}_{5}$ \\
1.844 & 8 & $\mathrm{Ca}_{2} \mathrm{Fe}_{2} \mathrm{O}_{5}$ \\
1.744 & 6 & $\mathrm{Ca}_{2} \mathrm{Fe}_{2} \mathrm{O}_{5}$ \\
1.644 & 6 & $\mathrm{Ca}_{2} \mathrm{Fe}_{2} \mathrm{O}_{5}$ \\
1.394 & 6 & $\mathrm{Ca}_{2} \mathrm{Fe}_{2} \mathrm{O}_{5}$ \\
1.398 & 5 & $\mathrm{Ca}_{2} \mathrm{Fe}_{2} \mathrm{O}_{5}$ \\
\hline
\end{tabular}

ASTM Card No: ${ }^{\mathrm{a}} 19-222,{ }^{\mathrm{b}} 28-775$.

used is that it does not involve milling of the precursor which is necessary in the conventional ceramic method. The milling introduces defects and strains in ferrite obtained which in turn affects its permanent magnetic properties.

\section{Acknowledgement}

One of the authors (KJS) is thankful to CSIR, New Delhi, for financial assistance.

\section{References}

Bassi P S, Randhawa B S and Sandeep Kaur 1989 Advances in ferrites (Proceedings of ICF-5) (New Delhi: Oxford Publ. Co.) p. 67

Bhide V G 1973 Mössbauer effect and its applications (New Delhi: Tata McGraw Hill Publ. Co.)

Cox D E, Shirane G and Ruby S L 1962 Phys. Rev. 125 1163

Ferraro J R, Driver R, Walker W R and Wozniak W 1967 Inorg. Chem. 61586

Greenwood N N and Gibb T C 1971 Mössbauer spectroscopy (London: Chapman and Hall Ltd.)

Grenier J C, Wattiaux A, Fourner L, Pouchard M and Etourneau J 1997 J. Phys. 7 C $_{1}-49$

Kulkarni G U, Kannan K R, Arunarkavalli T and Rao C N R 1994 Phys. Rev. B49 528

Nakamoto K 1970 Infrared spectra of inorganic and coordination compounds (New York: John Wiley Interscience) 2nd ed.

Randhawa B S and Kamaljeet Sweety 1998 J. Radioanal. Nucl. Chem. Letts 238141

Randhawa B S, Prabhjinder Kaur and Kamaljeet Sweety 1996 J. Radioanal. Nucl. Chem. 214447

Vertes A, Korecz L and Burger K 1979 Mössbauer spectroscopy (New York: Elsevier) p. 47

Viswanathan B and Murthy V R K 1990 Ferrite materials (Berlin: Springer-Verlag) 